\title{
Janusz Bujak,
}

\section{„Mężczyzna i niewiasta stworzyt ich”. Wspótczesny feminizm w poszukiwaniu tożsamości kobiety, Szczecin 2014, 194 s.}

W ostatnich latach ideologia gender i feminizm zdominowały medialne debaty, a także na dobre weszły do akademickich i szkolnych programów edukacyjnych. Natłok informacji na ten temat powoduje swoisty chaos intelektualny wołający o usystematyzowanie i obnażenie całej prawdy o tej jakże zgubnej dla człowieka ideologii. W usystematyzowaniu tym, z racji na coraz to większą niewiarę współczesnego człowieka, nie tyle chodzi o ukazanie sprzeczności gender z zamysłem stwórczym Boga, ile raczej o sięgnięcie do przesłanek rozumu i prawa naturalnego.

Ważnym wydaje się także odwołanie się do początków czy źródeł w znaczeniu chronologicznym feminizmu i ideologii gender, a także zdemaskowanie fałszywych oskarżeń kierowanych pod adresem chrześcijaństwa, szczególnie Kościoła katolickiego, który miałby „odczłowieczać" kobietę i czynić z niej jedynie przedmiot we władaniu mężczyzny, służący celom prokreacyjnym.

Wydaje się, że taki zamiar przyświecał pracy badawczej ks. prof. Janusza Bujaka, który został ukoronowany pozycją naukową pt. „Mężczyzna i niewiasta stworzyt ich"? Wspótczesny feminizm w poszukiwaniu tożsamości kobiety.

Praca ks. Bujaka ma podwójny walor: przedstawia zagadnienie w świetle jego historii, a także jest jego dogłębną analizą teologicznofilozoficzną. Autor więc w swoim opracowaniu całościowo ujął zagadnienie feminizmu, ze szczególnym zaakcentowaniem genderyzmu. $\mathrm{Pu}-$ blikację można określić jako kompendium wiedzy na wskazane tematy.

W swoim studium Autor wychodzi od próby określenia miejsca i roli kobiety w starożytności greckiej, rzymskiej i żydowskiej, aby na jej tle ukazać przełomowe, wręcz rewolucyjne jej rozumienie w życiu 
Sprawozdania i recenzje i nauczaniu Jezusa Chrystusa. Ukazuje kobiety towarzyszące Jezusowi i obecne w pierwotnym Kościele, podejmuje temat małżeństwa, dzieciobójstwa , rozwodów, zamążpójścia i dzietności, a także zagadnienie prostytucji.

Ksiądz Bujak, idąc tropem nauczania Jezusa i życia pierwotnego Kościoła ukazuje zagadnienia te w świetle personalizmu, oczywistego napiętnowania zła, ale także szacunku do każdej osoby ludzkiej, bez względu na płeć czy sposób życia.

Tak zarysowany „chrześcijański feminizm” stanowi preludium do ukazania pierwszej fali „wywrotowego feminizmu”, który był odpowiedzią na kalwińskie rozumienie miejsca i roli kobiety w społeczeństwie, jakie mieściło się w powiedzeniu ,,jestem tylko gospodynią domową”. Stąd, konkluduje Autor, zrozumiałym staje się protest przeciwko takiej sytuacji.

Systematyzując dzieje feminizmu ks. Bujak wskazuje na drugi jego okres, którego początkiem stała się inspirowana ideologią marksistowską rewolucja studentów roku 1968. Uderzyła ona w ówczesne autorytety, a w rezultacie przerzedziła także szeregi kościelne. Autor podejmuje próbę zbilansowania tego okresu, dostrzegając jego plusy i minusy. Do pierwszych zalicza większą możliwość dialogu w ramach rozmaitych instytucji, do drugich zaś zjawisko kontrkultury, antyhumanizmu i pogardy dla wartości chrześcijańskich oraz dążenie do „przyjemności bez reguł”, co pociągnęło za sobą rewolucję seksualną.

Ksiądz Profesor diagnozuje ostateczną przyczynę takiego stanu rzeczy. Jest nią bez wątpienia marksizm, który ukształtował świadomość ówczesnych feministek. To właśnie wówczas podjęto walkę z małżeństwem, macierzyństwem, rodziną, a zaczęto promować homoseksualizm, seksualne wyzwolenie dzieci aż do legalizacji związków kazirodczych i molestowania. W tym też okresie tworzą się women's studies i studia nad problematyką własnej płci. Zdaniem Autora, dały one impuls „trzeciej fali feminizmu” - feminizmowi gender. W trzecim rozdziale książki ks. Bujak stawia sobie za cel prezentację tej ideologii, szeroko ją omawia i komentuje, co bez wątpienia świadczy o jego wielkiej erudycji, znajomości tematu w spojrzeniu znacznie szerszym niż tylko antropologii teologicznej, bo sięgającym także do antropologii filozoficznej i etyki. Należy nadmienić, że narrator swobodnie porusza się w na płaszczyźnie tych nauk. Ten rozdział pracy pokazuje ogromne przywiązywanie wagi przez niego do kwestii terminologicznych. Sięga on do etymologii i dokładnie omawia różnice pomiędzy płcią i gender, naturą i kulturą. Cytuje przy tym wypowiedzi wielu ekspertów z dziedziny, zarówno zwolenników ideologii, jak i jej przeciwników. W ramy 
interesującego tematu Autor wprowadza i poddaje głębokiej analizie pojęcie queer, rozumiane w kontekście interseksualności człowieka.

Praca ks. Bujaka demaskuje także międzynarodowe organizacje wspierające gender. Należą do nich Organizacja Narodów Zjednoczonych, Komisja Europejska i Parlament w Strasburgu, które według niego, w wielu dokumentach i inicjatywach, z pominięciem prawdy, usiłują zalegalizować postawy sprzeciwiające się ustanowionemu porządkowi natury.

W czwartym rozdziale opracowania ks. Bujak sięga do istoty swoich naukowych zainteresowań i prezentuje feministyczną teologię i etykę. W ten sposób wprowadza do polskiej teologii myślicieli tematu nurtu radykalnego i reformistycznego zakreślając ramy teologii genetywnych, teologii wyzwolenia kobiet spod dominacji mężczyzn poprzez poszukiwanie modeli wyzwolenia w Piśmie Świętym i Tradycji Kościoła. W kwestiach teologicznych Autor akcentuje dwa zagadnienia widziane przez pryzmat feminizmu: płci Jezusa Chrystusa i Maryi w kontekście jej kobiecości. W ich przedstawieniu odnosi się do refleksji teolożek zachodnich, a także rodzimych, akcentując Elżbietę Adamiak.

W nurcie zagadnień teologii feministycznej Autor podejmuje polemikę ze zwolennikami święceń kapłańskich kobiet. Reprezentując w tym względzie nurt tradycyjno-konserwatywny przywołuje rozmaite stanowiska uzasadniające praktykę Kościoła katolickiego i prawosławnego, choć nietrudno wywnioskować jego szczególne zamiłowanie do teologii chrześcijańskiego Wschodu i wypracowanego przez nią pojęcia ikoniczności.

W opracowaniu ks. Bujaka doniosłą rolę odgrywa także zagadnienie etyki feministycznej widzianej przez pryzmat prawa naturalnego. To ostatnie jest marginalizowane, bądź pomijane, czy też negowane przez współczesne, liberalne prądy filozoficzne, stąd zwrócenie na to zagadnienie uwagi wydaje się być w tym opracowaniu szczególnie cenne. Autor uzupełnia je nauczaniem Magisterium Kościoła, przede wszystkim papieża Benedykta XVI.

Opracowane przez ks. Bujaka zagadnienia są głęboko osadzone w źródłach, przede wszystkim obcojęzycznych, co z polskiego punktu widzenia daje możliwość szerszego spojrzenia na zagadnienie z jednoczesnym sięgnięciem do jego korzeni. Są to źródła odnoszące się bezpośrednio do zagadnienia, np. pisma twórców ideologii, jak i głosy ją obalające, także z nurtu nauczania Kościoła i chrześcijańskiej antropologii, czerpiącej ze Wschodu i Zachodu. Za dobrym wykorzystaniem źródeł przemawia także struktura pracy ułożona klasycznie, w logiczną całość. 
Autor posługuje się metodą nietypową dla tego rodzaju opracowań - bezpośredniego odnoszenia się do źródeł, bez szczegółowego ich cytowania, umieszczając je jedynie w spisie bibliograficznym. $Z$ jednej strony przemawia to za doskonałą znajomością tematu, a z drugiej może być pewnym utrudnieniem dla pragnących głębiej sięgnąć do źródeł wykorzystanych w opracowaniu. Należy też podkreślić wykorzystanie przez Autora metody syntetycznej, która pozwoliła ująć zagadnienie w sposób niezwykle aktualny i domagający się szczegółowego zgłębienia nie tylko przez teologów i filozofów, ale także przez wszystkich, dla których ważną jest prawda o człowieku jako spotkaniu dwóch komplementarnych bytów: mężczyzny i kobiety. W tym też dostrzegam istotny wymiar pracy. 